\section{THE ARMY MEDICAL STAFF.}

We have been favoured by Sir Andrew Clark with a copy of the following correspondence between the Secretary of State for War and himself :-

Royal College of Physicians, London, March 7 th, 1891.

\section{Dear Mr. Stanhope,-}

Immediately on receiving the letter which you did me the honour to address to me as leader of the deputation from the medical corporations of the United Kingdom, on behalf of the grievances of the army medical officers, I placed myself in communication with those bodies for the purpose of ascertaining their views of the replies which you had made through me to their representations. Having now received answers from all of them, and their views being in complete accord with my own, I venture again to address you in this letter, with the desire to promote such an issue to these negotiations as will prove at once just and satisfactory to the medical officers of the army, and of real and lasting advantage to the State.

Although I am well assured of your unaffected desire to deal generously with the army medical officers, and to grant to their just grievances every just and practicable remedy, although I fully recognise the difficulties of your position as a Minister of State, standing between the army, the Government, and the House of commons, and can understand somewhat of the obstacles in the way of reconciling them to such a reform as we seek, I am constrained to acquaint you with the unanimous judgment at which we have arrived - that the concessions made to our representations are, with one exception, unsatisfactory, and that they fall far short, not merely of what is claimed by the medical officers, but also of what has been recommended by Parliamentary and War Office Committees, and of what has been regarded as just by men experienced in public affairs.

For my own part, I regard this unhappy result as due to the strange misapprehensions and the inaccurate statements of those who have supplied you with technical information upon the subject; and I cannot understand how our arguments should have been met by replies which could be immediately refuted by reference to official regulations. This is a grave statement to make, and did I not know that in dealing one by one with the paragraphs of your letter I should be able to make the statement good, it would not assuredly have been made.

Here, in order to illustrate this allegation, and to prove its accuracy, I must anticipate what I shall have to say at the close of this letter.

It is averred that "to incorporate the medical staff into the general army, and to give its officers substantive rank and military titles ...... would have the effect of placing a medical officer in military command over troops in the field whenever one might happen to be the senior officer present." Now this is the supreme objection made to conceding the claims of the medical officers, and, strange to say, it is absolutely without foundation, for in various places in the books of official regulations express provision is made for the granting of rank and title without command in the field, and for the granting of rank and title either with no command at all, or with such a limited command as may be defined on appointment. In the Royal Warrant of 1890 , paragraph $69 \mathrm{~A}$, we read as follows :- "An officer permanently transferred from the commissariat and transport staff to the supernumerary list of our Army Service Corps shall not hold any military command outside our Army Service Corps, except over such officers and men as may be specially placed under his command." "An officer of our Army Service Corps detailed for barrack duties shall not hold any military command, except over such officers and men as may be specially placed under his command." And again, even more ex plicitly, we read in paragraph 70 that " an officer of our army employed in any of the cases specified in Article 50 (h) or (i) shall not be entitled by virtue of his military rank to assume any military command in our regular army, unless called out for military duty by our Secretary of State." Surely neither the claims of reason nor the neces sities of experience could require more conclusive proof that the granting of military rank and title does not necessarily imply or involve the granting of military command in the field.
With your permission I will now proceed to deal with those paragraphs of your letter which have a crucial bearing upon the questions under discussion.

Paragraph 10.-You state that the only way of lengthening the home service of medical officers is to increase the numbers employed at home ; that this could be done only by employing them upon duties which would occupy but a small portion of their time; that they would thereby lose experience and deteriorate in professional knowledge that an increase of establishment necessary to lengthen the period of home service would cost $£ 27,000$ a year ; and that therefore you are unable to grant this request. Now I must be permitted to point out that this subject has not been brought fairly before you, and that this answer is entirely irrelevant to the relief sought for by the army medical officers. They do not ask for a shorter term of foreign service, and they do not ask for a longer term of home service. They only ask for a shorter term of continuous foreign service; they ask only to be restored to the rule which was in operation before 1888 they ask only that, unless in cases of State emergency, the term of continuous foreign service should be limited to five years instead of six years; and they allege-justly, I think-that the granting of this relief would not only not lengthen, but distinctly shorten, the duration of continuous service at home. This relief is asked by the army medical officers on grounds not less important to the State than to themselves. It has been found that the additional year of foreign service imposed in 1888 upon the army medical officers, more exposed than any others to the active causes of disease, has notably increased the rates of their sickness and mortality, and has, without compensating advantage to the State, added to its burden a growing list of noneffective medical officers. Furthermore, it was declared by your own committee, the Camperdown Committee, that the grounds upon which this relief was sought were just grounds, and they recommended that the new rule should be abrogated and the old rule restored. Finally, having regard to the conduct of medical affairs before 1888, when the term of continuous foreign service, which acted well, was enlarged from five to six years, to the fact that the number of medical officers is about the same now as it was then, and to the circumstance that facilities for drafting are greater at present than at any former period, and that the services of medical officers may be utilised in the troopships so employed, there does not appear to exist any valid reason why, if this request were granted, the somewhat more frequent transport of medical officers, involved in the grant, should necessitate the introduction of new machinery, the enlargement of some existing establishment, or any material addition to present expenditure.

Paragraph 2.-Your concessions as to the conditions for the granting of sick leave to medical officers have been received with uniform and grateful satisfaction, not only by the Army Medical Staff, but also by the whole body of the medical profession which takes an active interest in the just settlement of the questions considered in this correspondence.

Paragraph 3.-In reply to the complaint that the army medical officers do not receive a fair share of the honour and rewards conferred upon officers generally for exceptional services to the State in warlike and other expeditions, you observe that such rewards can hardly be made a matter of proportion, and that the granting of them must necessarily depend on the opportunities which officers, whether com batant or medical, have of distinguishing themselves. The force of these general remarks need not be denied; but the contention of the army medical officers and the contention and recommendations of Sir Ralph Thompson's Committee do not lie within their limits. The contention of the army medical officers is that, in like circumstances of perils encountered, hardships endured, and services rendered in successful expeditions, they should obtain a fair share of the honours bestowed upon such occasions. The contention of Sir Ralph Thompson's Committee of 1878 is that, judged by the standard about to be mentioned, the medical oflicers are tar below the combatant ranks in their enjoyment of the honours of the Bath, the Star of India, and the Star of St. Michael and St. George ; and the committee recommends that in regard to honours, rewards, and good service pensions the medical department should be judged rather by the standard for combatants than by that for non-combatants I am aware that it is contended by the combatant officers of the army that the medical department receives more than 
its fair share of honours and rewards. His Royal Highness the Commander-in. Chief asserts that the army medical officers " have absolutely got such an excess of honours and rewards at the present time that we cannot give then any now," and he adds that the "honours and rewards are all apportioned most carefully." Sir Archibald Alison, Lord Wolseley, General Harman, and other distinguished combatant officers follow in a similar strain. As a matter of fact, however, these statements are incapable of sustaining any critical examination, and a reference to official returns brings immediately to light the conclusive evidence of their complete inaccuracy.

In illustration of the gravely inaccurate information with which you have been supplied on this subject, let me compare the honours bestowed upon the Engineers with honours bestowed upon the Army Medical Staff.

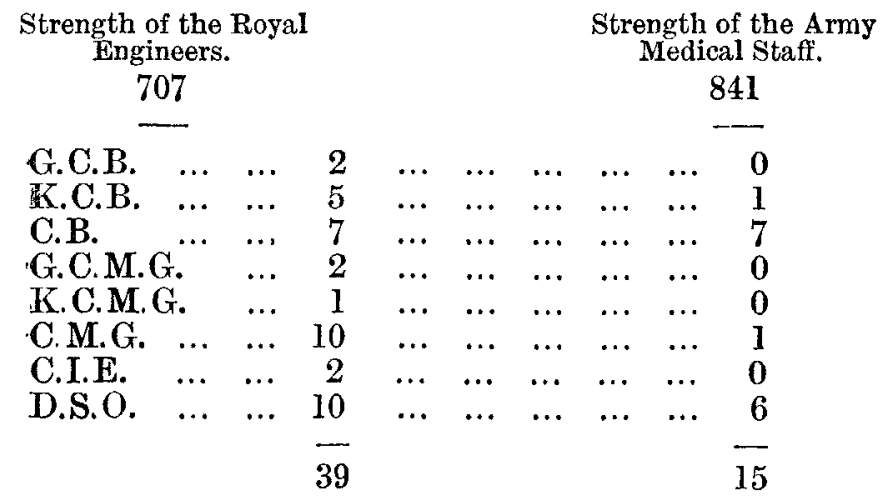

Percentage of honours to strength, R.E., $5 \cdot 6$ A.M.S., $1 \cdot 7$. Furthermore, of the Egyptian decorations conferred in 1882 the percentage to strength was :-

For the Ordnance Store Department... $\quad \ldots \quad \ldots \quad \ldots \quad 57$

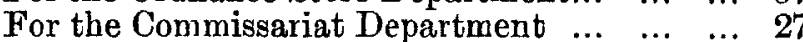

For the Medical Department

Finally, in respect of the Nile Expedition of 1884, the percentage to strength of promotions among departmental officers was as follows:-

Chaplains...

Pay Department

$\begin{array}{llllllllll}\text { Ordnance } \ldots & \ldots & \ldots & \ldots & \ldots & \ldots & \ldots & \ldots & \ldots & 30\end{array}$

41

Medical Statf

Such illustrations could be largely added to ; but I have adduced already a number sufficient to show that whilst the contentions of the medical officers of Sir Ralph Thompson's Committee and of Director-General Crawford are grounded on official records and are accurate, the contention of the combatant officers is grounded on merely emotional im. pressions and is inaccurate.

In view of these facts, and especially in view of this further fact, that more than one War Office Commission has recognised the existence and acknowledged the justice of this ground of complaint, we have received with disappointment your decision on this subject.

The matters alluded to in paragraphs $4,5,6$, and 7 are not of serious importance to the settlement of the main question at issue, and, having been mentioned more by way of illustration of the chronic attitude of mind preserved by combatant officers and high officials towards the medical officers than for the purpose of making any present claim for their reform, are herewith set aside. Nevertheless such matters have some importance, and men of the world acquainted with military organisation, the drift of social opinion, and the general tendencies of the age will think it neither wise nor safe entirely to ignore them.

Permit me to give two illustrations of the matters referred to in the paragraphs specified. When Surgeon-General Sir Anthony Home received the Victoria Cross for his heroic defence of the wounded in a street at Lucknow, he was the only officer decorated on the occasion who was not afterwards invited to the Palace. He felt the slight so keenly that for years afterwards he refused to wear the decoration which he had so honourably won. Again, and in like manner, when Surgeon Reynolds received the Victoria Cross for his gallant conduct at Rorke's Drift, his companion, an officer of Engineers, was afterwards invited to the Palace, but Surgeon Reynolds was passed over unnoticed. He did not belong, one might infer, to the same caste, and he was therefore unfit to sit with any combatant officer above the salt. To those who do not understand the ways of the world of military life these may seem to be small things unworthy of consideration, but to those who enter in to the constitution of military society, and to most persons who understand it aright, they are symbols of things which in the aggregate become serious, inasmuch as they tend to foster discord, disaffection, and distrust, and to man with growingly inferior persons a department upon which the nation depends for the safety of its army in peace and for the conditions essential to its success in war.

Paragraph 8.-In this paragraph you are pleased to concede to the army medicul officers the composite titles recommended by the Camperdown Commission, and you " trust that this concession will put an end to the regrettable agitation which has obscured the true bearings of this important matter." Unfortunately, however, this is the concession of title alone and of nothing else. But it is not title by itself for which the medical officers con. tend: it is for some such title as will carry with it the guarantee of substantive rank; since they declare that without such rank they are unable to discharge in the prompt, thorough, and acceptable manner which they desire the military duties and responsibilities now imposed upon them; and they earnestly maintain that title without an accompanying guarantee of substantive military rank is absolutely worthless for the remedy of any grievance of which they have just cause of complaint. This conten tion of the army medical officers has received a kind and measure of support perhaps never before accorded to any like demand for class reform. It is supported by the ex. perience of the armies of Italy, Switzerland, Holland, Turkey, the United States, and of several other countries; by the opinion of all the medical corporations of the United Kingdom ; by the conclusions of almost all bodies of men who have judicially investigated the question; and even by the approval of a rapidly growing number of combatant officers. Furthermore, this plan of incorporating the medical officers into the general army and giving them substantive rank therein has never bitherto failed, where it has been tried, to allay dissatisfaction, to promote unity and efficiency of action, and to secure for the medical service higher men and better work.

But there lies in this question still another fact, which, although it is at the root of the whole discussion and of the first importance in its just settlement, has been either overlooked or jgnored by your military advisers. Army medical officers are not merely doctors; they are doctors whom the progress of ideas and the march of modern warfare have made of necessity soldiers also; and the further they advance in the service the more important and the more purely military their duties become. As surgeon, the army medical officer has to discharge all military duties and responsibilities except the one of actual fighting in the field. Chief among them I may mention the command and discipline of the Medical Staff Corps and of all persons either attached to the corps or else on duty in the military hospitals, the instruction of the corps in infantry and stretcher drill, the management of the pay, clothing, and general equipment of the Medical Staff Corps, the accounting of officers for hospital buildings, general supplies, and necessary stores, the study of military law and its administration in minor offences. Furthermore, in charge of a field hospital and responsible for a hundred sick, he has military command of four officers and a hundred and seventy. one non-commissioned officers and men ; whilst in charge of a bearer company in action, and possibly under fire, he has military command of three officers and one hundred and one non-commissioned officers and men, and he may himself have to fight in defence of his sick. As a surgeon-general, the army medical officer has the military command of nearly three hundred officers and of fifteen hundred non-commissioned officers and men of the medical staff and the Medical Staff Corps; he has the control of probably two thousand sick, and he has to settle in all its complexity of details the medical organisation which may become necessary for the injuries and diseases of forty thousand men.

It seems to me that to deal with an official having responsibilities of such moment as if he were merely a doctor, as if he were not a real officer, as if he were not entitled to rank as combatants rank, and as if he were not worthy of being incorporated into the general army, is at once a serious anomaly, a tactical mistake, and a grave injustice. For if this surgeon-general were not acquainted with military organisation, if he had not studied the economy of armies, if he did not understand military 
strategy, if he were not capable of making adequate provision for transport and of establishing secure bases for supplies, if be were not experienced in the command of men, and if he were not in heart as true a soldier as any on the field, he would be utterly incapable of making those preparations for action without which, in the present day, it is probable that no great battle could be fought and won.

And now, in the last place, as respects the supreme objection to the granting of substantive military rank to medical officers-the objection that it implies and involves the granting of military command in the field, - I venture to remind you that in the beginning of this letter I have conclusively proved from the Royal Warrant of 1890 that this objection has no valid existence, and that definite provision has been made for the granting of rank and title in special circumstances without command. And I may be permitted further to remind you that at this time there are to be found in the army numerous officers of almost all ranks who have no combatant command. The granting of sub. stantive rank to medical officers, therefore, would and could do no more than confirm them in the command with which they are already invested over the Army Medical Corps, and enable them to discharge their duties unencumbered by the trials and difficulties with which they are now surrounded.

The more widely I have considered this subject of the grievances of the army medical officers, and the more critically I have weighed what has been said on both sides of the discussion, the more deeply have I become convinced that those grievances are just, that they require but one remedy for their cure, that no other but this one remedy will succeed in curing, and that to the adoption of it no sound and substantial objection can be taken and maintained. In the presence of this conviction I pursue no further the exposure of the misapprehension and inaccuracies which have crept into the "combatant" side of the discussion. I set aside as covered and satisfied by the main issue all collateral questions of loss of pay, place on courts-martial, comparison with Engineers, and others referred to in your letter, and I content myself with declaring on the part of the medical corporations of the United Kingdom, whom on this occasion I have the honour to represent, their unanimous judgment that the only remedy for the full and just relief of the grievances of the army medical officers is the conversion of the whole Army Medical Department into a Royal Army Medical Corps, and the granting of substantive military rank and title to all its officers.

We firmly believe that if this conversion were effected agitation and disaffection would cease, frequently recurring discords and difficulties would disappear, unity and concord would be restored, the best order of men wruld seek the medical service, and the naturally high and generous instincts of the combatant officers would soon reconcile themselves to a change which could not fail to bring about increasing advantages to the soldier and higher service to the State.-I am, dear Mr. Stanhope, yours faithfully,

The Right Hon. Edward Stanhope, M.P., ANDREW ClARK. Secretary of State for War.

War Office, Pall Mall S.W. Iarch 17th, 1891

SIR, - I have the honour to acknowledge your letter of the 7th inst. You refer to the concessions made in my letter of Feb. 2nd as unsatisfactory, and again impute that condition of things to the "strange misapprehension and inaccurate statements" of those who have supplied me with the information which you say can be immediately refuted by reference to official regulations.

In proof of this most serious allegation, you quote paragraph 8 of my letter, and you then show, from military regulations, that military rank does not necessarily carry more than a limited command, and can be, and often is, limited in its scope; and you therefore characterise my objection to incorporate the Medical Staff into the general army as absolutely without foundation. These are strong statements, and they are as wrong as they are strong.

In your letter of Jan. 17th you asked for "the transformation of the whole department into a Royal Army Medical Corps with definite rank and title to all its officers and its organic incorporation into the general army on the lines followed in the case of the Royal Engineers." These words carry but one meaning to my mind, and to that meaning there must be the fatal objection described in my letter, and I can only conceive that you labour under a total misapprehension of the powers of officers of the Royal Engineers.

I am quite aware that the function of command can be limited, and in the sume paragraph $I$ pointed ont that medical officers actually have this limited command, which they derive from the substantive rank given them by their commissions.

As regards the length of foreign service of medical officers, you say that my answer is " entirely irrelevant to the relief sought for." I should be very sorry if I had consciously or unconsciously misrepresented what these officers wish for, but I would point out to you that your mention of the subject was of the baldest possible description, and from. your reference to the Camperdown Committee I was led to suppose that your proposal was identical with the recommendation of that Committee. That recommendation was that continuous service abroad should not exceed five years, and that more home service should be given. to army medical officers by employing them in posts now filled by retired medical officers (vide paragraph 5 of report).

It was to this that my remark as to the great expense of the change applied. If, however, what is asked for is merely a slight rearrangement of the periods of foreign service not involving longer home service, I will consider what I can do to meet their wishes. I should, however, say that such a concession would be a doubtful boon, and might possibly not be appreciated by many of the officers concerned. Such shortened periods of foreign service would mean more frequent changes, and each change of station means some cost to the officer.

As regards the grant of honours, I can only repeat what seems to me to be a self.evident proposition-viz, that it cannot be made a matter of proportion, but must depend on the opportunities which officers have of distinguishing themselves. The fact that the Engineer honours are for the moment in excess of those enjoyed by the Medical Staff in no way lessens the force of my statement.

The Engineers obtain rewards for services not only in the army but in innumerable civil positions, and they have that very qualification of command which you admit should not be given to officers of the Medical Department. If you will eliminate from the list you give of Engineer rewards those gained in civil and colonial employ and in high command, you will find the two lists are not disproportionate.

On the question of Court privileges, I have already said that I would consult with the proper authorities.

The concluding portion of your letter rejects the conces. sion which I made in accordance with your own suggestion. You say that medical officers " contend for some such title as will carry with it the guarantee of substantive rank to enable them to discharge the military duties and responsibilities now imposed on them." On this point there is evidently some misunderstanding on your part. Substantive rank Army Medical officers already have by virtue of their commissions to the full extent you ask for, and no grant of military titles of any description will change or in. crease it.

I regret very much to be at variance on this point with the distinguished profession which you so ably represent, but I am satisfied that it is not desirable to give medical officers the power to assume the active command of troops in the field or in quarters, and that were I to allow their formation into the corps you propose, and their "organic incorporation into the general Army on the lines followed in the case of the Royal Engineers," this command could not be denied them. I am not therefore prepared to do more than give the composite titles which, as I have already remarked, was your own proposal, and which was also the recommendation of Lord Camperdown's Committee, of which representatives of the profession nominated by the Royal Colleges of Physicians and Surgeons were members.

Having therefore adopted one of the alternatives which you have yourself put forward, I do not think that any object would be gained by any further correspondence on the subject.

I have the honour to be, Sir, your obedient servant, EDWARD STANHOPE.

Sir Andrew Clark, Bart, M.D., F.R.S., \&c. 